ність стандартної ПВТ і визначати терапевтичну тактику у хворих на ХГС.

2. Плануючи й офрормляючи лист очікування ПВТ у хворих з генотипом $1 \mathrm{HCV}$, доцільно здійснювати поділ на три категорії за стадією фріброзу та ймовірністю досягнення СВВ: I - пацієнти, яким показана стандартна ПВТ, II - пацієнти, яким показана потрійна терапія, III пацієнти, у яких ПВТ можна відкласти.

3. Стандартна ПВТ у разі досягнення СВВ понад 50 \% показана 24,2 \% хворих з генотипом 1 і всім пацієнтам 3 генотипом $2 / 3 \mathrm{HCV}$.

\section{Література}

1. From non-A, non-B hepatitis to hepatitis $C$ virus cure / J.M. Pawlotsky, J.J. Feld, S. Zeuzem, J.H. Hoofnagle // J. Hepatology. - 2015. - Vol. 62. - S87-99.

2. Hepatology 2015 / [S. Mauss, T. Berg, J. Rockstroh et al.] // Clin. Nextbook. - 2015. - S650.

3. Boceprevir for untreated chronic HCV genotype 1 infection / [F. Poordad, J.Jr. McCone, B.R. Bacon et al.] // N. Engl. J. Med. - 2011. - Vol. 364. - P. 1195-1206.

4. UK consensus guidelines for the use of the protease inhibitors boceprevir and telaprevir in genotype 1 chronic hepatitis Cinfected patients / [P. Ramachandran, A. Fraser, K. Agarwal et al.] // Aliment. Pharmacol. Ther. - 2012. - Vol. 35. - P. 647-662.

5. Уніфікований клінічний протокол первинної, вторинної (спеціалізованої) медичної допомоги дорослим та дітям. Вірусній гепатит С, 2014. (Наказ МОЗ України № 233 від 02.04.2014).
6. HCV-GenoFibrotest: a combination of viral, liver and genomic (IL28b, ITPA, UGT1A1) biomarkers for predicting treatment response in patients with chronic hepatitis C / [J.M. Costa, D. Telehin, M. Munteanu et al.] // Clin. Res. Hepatol. Gastroenterol. - 2011. - Vol. 35, N 3. - P. 204-213

7. Зайцев И.А. Прогнозирование результатов противовирусной терапии больных хроническим вирусным гепатитом С / И.А. Зайцев // Гепатологія. - 2013. - № 2. - С. 4-13.

\section{PROGNOSIS OF EFFECTIVENESS AND CHOICE OF ANTIVIRAL THERAPY TACTICS IN PATIENTS WITH CHRONIC HEPATITIS C}

V.M. Kozko, O.Ye. Bondar, H.O. Solomennyk, N.V. Antsyferova, L.M. Amelina, D.B. Penkov

SUMMARY. The results of examination of 78 patients with chronic hepatitis $C$ with the HCV GenoFibroTest using were presented in the article. Recommendations for antiviral therapy tactics based on analysis of probability of getting sustained virological response according to the HCV genotype and the stadium of fibrosis were given.

Key words: chronic hepatitis C, prognosis, HCV GenoFibroTest, tactics of antiviral therapy.

Отримано 22.03.2015 p.

\title{
ПРОТИВІРУСНА ТЕРАПІЯ ПРИ 2,3 ГЕНОТИПІ ВІРУСУ ГЕПАТИТУ С: КЛІНІЧНИЙ ТА ЕКОНОМІЧНИЙ АНАЛІЗ ЇЇ ЕФЕКТИВНОСТІ
}

\author{
Донецький національний медичний університет ім. М. Горького, \\ Національний медичний університет ім. Богомольця, м. Київ
}

\begin{abstract}
Проведена оцінка порівняльної клінічної та економічної ефективності двох схем противірусної терапії хронічного гепатиту C, 2/3 генотипу вірусу HCV. Пацієнти групи A (п=25) отримували комбінацію інтерфрерону- $\alpha$ і рибавірину, пацієнти групи Б $(n=36)$ пегільованого інтерферону- $з$ рибавірином. Частота досягнення ранньої вірусологічної відповіді і відповіді на момент закінчення курсу терапії склала 80,0 і 94,3 \%,
\end{abstract}

CBВ - 72, 0 і 91,7 \% у групах А і Б відповідно ( $p>0,05$ для всіх показників). Порівняльний фрармакоекономічний аналіз двох схем противірусної терапії ХГС, генотип 2/3, продемонстрував, що більша ефрективність витрат характерна для комбінованої терапії $I \Phi H-\alpha$ + рибавірин. Ця схема терапії має значну економічну перевагу, якщо лікування хворих фрінансується за рахунок національних програм і ставиться завдання 


\section{ОРИГІНАЛЬНІ ДОСЛІДЖЕННЯ}

вилікувати не конкретного хворого, а якомога більшу кількість пацієнтів. Однак така схема лікування ХГС має меншу клінічну ефективність, тому для пацієнта більш привабливою залишається терапія ПЕГ-ІФН- $\alpha$ + рибавірин, що забезпечує більшу частоту CBB та менший за величиною показник ефективності вuтpam.

Ключові слова: хронічний гепатит С, пегільований інтерферон- $\alpha$, інтерфрерон- $\alpha$, рибавірин, фрармакоекономічний аналіз.

Проблема гепатиту С довгі роки залишається однією 3 найактуальніших в медицині та охороні здоров'я [1]. Визнано, що HCV-інфекція - одна з основних причин розвитку хронічних захворювань печінки, включаючи цироз печінки і гепатоцелюлярну карциному, а також $€$ основним показанням до трансплантації печінки. У світі гепатитом C (ГС) щорічно інфрікуються 3-4 млн осіб, 200 млн страждають на хронічну фрорму цього захворювання. Від наслідків HCV-інфекції щорічно вмирають близько 1 млн осіб [2, 3]. За даними ВООЗ, в Україні ГС інфріковано близько 1,2 млн осіб, що становить приблизно 3 \% від загального населення $[4,5,6]$.

Противірусна терапія (ПВТ) хронічного гепатиту С (ХГС), особливо комбінація пегільованого інтерферону і рибавірину, досить есрективна. Частота стійкої вірусологічної відповіді (CBB) на лікування Пегінтердероном а-2а і рибавірином у хворих з генотипом 1 досягає $60 \%$ $[7,8,9]$, а у пацієнтів 3 генотипами 2 і 3 - $84 \%[10,11]$. При застосуванні пегільованого інтерферону а-2b i рибавірину ці показники становлять 42 і 81 \% відповідно $[12,13,14]$. Однак через свою дорожнечу пегільовані інтерферони не доступні більшості інфрікованих в Україні. Висока вартість оригінальних препаратів ПегІФН, представлених на українському ринку, обмежує їх застосування в Україні невеликою групою пацієнтів із величезної кількості осіб, які потребують цю терапію. Доступною альтернативою в українській практиці вважається комбінована терапія стандартними інтерферонами і рибавірином. У зв'язку з цим представляють інтерес дані про перспективність використання для лікування ХГС стандартних інтерферонів. Особливо це актуально для хворих, інфікованих «сприятливими» 2/3 генотипами вірусу, в яких СВВ із застосуванням стандартних інтерферонів становить $66 \%$, при 1 генотипі вірусу HCV - це всього лише $28 \%$ [15].

Висока вартість лікування HCV-інфекції вимагає зваженого підходу до вибору оптимальної тактики 3 урахуванням економічних витрат, оскільки найбільш есрективна схема противірусної терапії з використанням ПЕГ ІФН- $а$ за своєю вартістю в 3-4 рази перевищує вартість стандартного інтерферону [16, 17], в той же час різниця в ефективності складає всього лише 10-15 \%. Тобто сучасні схеми противірусної терапії створюють суттєві фрінансові проблеми для хворих і системи охорони здоров'я в цілому. Кошти, які виділяє держава на лікування, обмежені, тому вельми актуальною є проблема їх раціонального використання. 3 точки зору фармакоекономіки оптимальним $€$ такий варіант, коли при мінімумі витрат можна отримати максимальний ефект. Це диктує необхідність оцінки клінічної та економічної ефективності представлених режимів ПВТ ХГС.

Зіставити витрати та переваги, одержувані при різному використанні обмежених фрінансових ресурсів, дозволяє фармакоекономічний аналіз. Оскільки будь-яке обмеження ресурсів робить неминучим певний вибір, фрармакоекономічний аналіз дає можливість зробити цей вибір більш раціональним і більш ефективно витрачати кошти державного бюджету, медичного страхування або особистих грошей пацієнта [18, 19].

Мета дослідження - визначити найбільш економічно ефрективну схему противірусної терапії в Україні у хворих на ХГС, інфрікованих 2/3 генотипом вірусу.

\section{Пацієнти і методи}

Відбір пацієнтів. У дослідження були включені хворі на ХГС, у яких діагноз був підтверджений виявленням антитіл до HCV не менше ніж за 6 місяців до початку терапії, інфрікованих 2/3-м генотипом вірусу, із підвищеним не менше ніж у 1,5 разу рівнем сироваткових трансаміназ. Усім хворим було проведено дослідження на наявність РНK HCV методом полімеразної ланцюгової реакції (ПЛР) і генотипування вірусу. Вірусне навантаження визначали методом кількісної ПЛР (Roche) з чутливістю 600 МО/мл і вище. У більшої частини пацієнтів діагноз хронічного гепатиту був підтверджений гістологічно, хоча відсутність результатів біопсії або відмова пацієнтів від ії проведення не були підставою для виключення хворих з дослідження.

Хворі з 1-м генотипом і клінічно очевидним цирозом печінки виключалися з дослідження. Також критеріями виключення з дослідження були інші захворювання печінки, ко-інфекція ВІЛ або вірусом гепатиту В; клінічно значущі гематологічні, ревматологічні, неврологічні, нефрологічні, психіатричні, серцево-судинні захворювання; метаболічні розлади; системні інфекції; злоякісні новоутворення; супутня імуносупресивна терапія; надмірне вживання алкоголю або наркотиків протягом попереднього року.

Дизайн і організація дослідження. У дослідження було включено 61 хворого на хронічний гепатит C, з 2/3 генотипом HCV. Пацієнтів розділили на дві групи, які були співставні за такими ключовими критеріями, як вік, стать, маса тіла, давність захворювання, активність аланінамінотрансферази (АлАТ), гістологічна активність і стадія захворювання. 


\section{ОРИГІНАЛЬНІ ДОСЛІДЖЕННЯ}

Пацієнти групи A $(n=25)$ отримували комбінацію інтерферону- $\alpha$ і рибавірину (Рофрерон-A, Roche (Швейцарія) по 3 млн МО 3 р. на тиждень і Копегус, Roche (Швейцарія), 15 мг/кг в день per os 2 р. на добу), пацієнти групи Б $(n=36)$ отримували комбіновану терапію пегільованим інтерфероном- $а$ рибавірином (Пегасис, Roche (Швейцарія) по 180 мкг на тиждень п/к і Копегус, Roche (Швейцарія) в аналогічному дозуванні. Терапію пацієнти отримували протягом 24 тижнів. Побічні ефекти класифрікувалися за виразністю на м'які, помірні і тяжкі. Стан пацієнтів і результати аналізів оцінювали протягом лікування на 1 , 2, 4, 8, 12, 16, 24 тижнях, а потім на 12 і 24 тижнях після припинення терапії. Рівень сироваткової РНК ВГС визначали перед лікуванням, через 12 тижнів проведення ПВТ, в кінці лікування, а також через 24 тижні після припинення лікування за допомогою методу ПЛР. Біопсія печінки проводилася двічі: до початку лікування і безпосередньо по його закінченні. Групова характеристика пацієнтів представлена в табл. 1.
У більшості хворих давність захворювання не перевищувала 10 років. Середній вік хворих склав 32,4ะ1,7 (від 21 до 56 років). Маса тіла обстежених коливалась від 52 до 84 кг. Індекс маси тіла в жодному випадку не перевищував 30. В обох групах превалювали особи молодого віку (до 40 років), більшу частину обстежених склали чоловіки (64,0 і 69,3 \%, відповідно). У групі хворих, що приймали ІФН- $\alpha 2 b$ + Рибавірин, АлАТ була підвищена у всіх пацієнтів, у 58,5\% мала місце мінімальна, у решти - помірна біохімічна активність захворювання. У групі хворих, що приймали ПегІФН$\alpha 2 a+$ Рибавірин, АлАТ була підвищена у 80,2 \% пацієнтів (3 них у 83,7 \% мала місце мінімальна і у 16,3 \% - помірна біохімічна активність захворювання). Вірусне навантаження у всіх пацієнтів не перевищувало $2 \times 10^{6}$ копій/мл. Гістологічні зміни були оцінені у 61 \% пацієнтів. Ознаки слабкого фріброзу печінки визначалися у 20,0 \% хворих у групі А і у 33,3 \% пацієнтів у групі Б, помірного - у 24,0 і 41,7 \%, вираженого - у 56,0 і 25,0 \% відповідно.

Таблиця 1

Клінічна характеристика пацієнтів у двох групах

\begin{tabular}{|c|c|c|}
\hline Демограсрічна ознака & ІФН- $\alpha 2 \mathrm{~b}+$ рибавірин $(\mathrm{n}=25)$ & $\begin{array}{c}\text { ПегІФН- } \alpha 2 a+\text { рибавірин } \\
(\mathrm{n}=36)\end{array}$ \\
\hline Число пацієнтів (чоловіки/жінки) & $16 / 9$ & $25 / 11$ \\
\hline Маса тіла, к ${ }^{\mathrm{a}}$ & $73,0 \pm 2,9$ & $74,6 \pm 9,5$ \\
\hline Вік, роки & $32,9 \pm 1,7$ & $31,9 \pm 1,8$ \\
\hline \multicolumn{3}{|l|}{ Біохімічні показники } \\
\hline АлАТ $\left(\times\right.$ ВГПН $\left.{ }^{a, *}\right)$ & $1,03 \pm 0,09$ & $1,90 \pm 2,00$ \\
\hline \multicolumn{3}{|l|}{ Дані генотипування } \\
\hline 2 генотип HCV & $5(20 \%)$ & $9(25 \%)$ \\
\hline З генотип HCV & $20(80 \%)$ & $27(75 \%)$ \\
\hline \multicolumn{3}{|c|}{ Гістологічна активність - число хворих (\%) } \\
\hline мінімальна & 0 & $6(50,0 \%)$ \\
\hline слабка & $10(40,0 \%)$ & $4(33,3 \%)$ \\
\hline помірна & $12(48,0 \%)$ & $2(16,7 \%)$ \\
\hline висока & $3(12,0 \%)$ & 0 \\
\hline \multicolumn{3}{|l|}{ Стадія фріброзу - число хворих (\%) } \\
\hline 0 & 0 & $1(8,3 \%)$ \\
\hline I & $5(20,0 \%)$ & $3(25,0 \%)$ \\
\hline II & $6(24,0 \%)$ & $5(41,7 \%)$ \\
\hline III & $11(44,0 \%)$ & $3(25,0 \%)$ \\
\hline IV & $3(12,0 \%)$ & 0 \\
\hline $\mathrm{V}$ & 0 & 0 \\
\hline
\end{tabular}

Примітки. - середнє значення \pm помилка середнього, * - верхня межа показника в нормі.

Оцінка ефективності. Головною кінцевою метою було досягнення стійкої вірусологічної відповіді (СВВ), що визначається по відсутності РНК НCV в сироватці через 24 тижні після завершення лікування. Вторинною кінцевою метою була нормалізація сироваткових трансаміназ і поліпшення гістологічної картини.

При проведенні фрармакоекономічного аналізу використані результати порівняльного клінічного дослідження двох схем лікування хворих на ХГС. Враховуючи відмінності в ефрективності порівнюваних схем терапії ХГС для фрармакоекономічної оцінки ми використовували метод витрати-ефективність, при якому проводиться порівняння як вартості (у грошовому вираженні), так і ефрективності (в однакових одиницях виміру) альтернативних медичних технологій і визначається, яка з порівнюваних альтернатив дозволяє досягти більшої ефективності витрат. За допомогою методу «витрати-ефективність» - визначали вартість одиниці ефрективності (питому ефективність витрат) і додаткову грошову суму, яку необхідно витратити на отримання додаткової переваги (інкрементальний 


\section{ОРИГІНАЛЬНІ ДОСЛІДЖЕННЯ}

показник при використанні більш ефективного та більш дорогого методу в порівнянні з ефрективним і більш дешевим).

Показник «витрати-есрективність» (cost-effectiveness ratio, CER) для кожної з аналізованих медичних технологій розраховували за формулою: CER=DC+IC/Ef, де DC - прямі витрати; IC - непрямі витрати; Ef - ефективність лікування в одиницях ефективності терапії. Величина CER показує вартість одиниці ефрективності при використанні відповідної медичної технології (схеми терапії).

Коефріцієнт приросту ефрективності витрат (інкрементальний показник ефективності витрат, incremental costeffectiveness ratio, ICER) розраховували за фрормулою: ICER=DC $-\mathrm{DC}_{2} / \mathrm{Ef}_{1}-\mathrm{Ef}_{2}$, где $\mathrm{DC}_{1}-$ прямі витрати при використанні першої медичної технології (схеми терапії); $\mathrm{DC}_{2}$ - прямі витрати при використанні другої медичної технології (схеми терапії); $\mathrm{Ef}_{1}$ и $\mathrm{Ef}_{2}$ - показники ефективності лікування в кількісному вираженні при використанні відповідно пер- шої та другої медичної технології. Величина ICER показує вартість додаткової одиниці ефективності при переході на більш ефективну медичну технологію (схему терапії).

У даному дослідженні враховували тільки витрати на фрармакотерапію, тобто вартість курсу лікарської терапії, використавши оптові ціни на препарати на листопад 2011 за даними інформаційно-аналітичної системи «Моріон».

\section{Результати досліджень та їх обговорення}

Характеристика ранньої вірусологічної відповіді (PBB - негативний результат виявлення PHK HCV через 12 тиж.), відповіді на момент закінчення лікування (ВЗЛ) і СВВ в групах А і Б наведені в табл. 2. Частота досягнення РВВ і ВЗЛ - 94,3 і 80 \%, СВВ - 91,7 і 72 \% відповідно ( $>0,05)$. Комбінована терапія ХГС ПегІФН і рибавірином була більш ефективною порівняно з комбінацією ІФН і рибавірину (табл. 2).

Таблиця 2

Вірусологічна та біохімічна відповідь на ПВТ хворих на ХГС

\begin{tabular}{|l|c|c|}
\hline \multicolumn{1}{|c|}{ N з відповіддю / загальне N пролікованих (\%) } & ПегІФН + рибавірин \\
\hline \multicolumn{2}{|c|}{ Вірусологічна відповідь } & $20 / 25(80 \%)$ \\
\hline Після 12 тижнів ПВТ & $34 / 36(94,3 \%)$ & $20 / 25(80 \%)$ \\
\hline До кінця лікування & $34 / 36(94,3 \%)$ & $18 / 25(72 \%)$ \\
\hline До кінця наступного спостереження & $33 / 36(91,7 \%)$ & $21 / 25(84 \%)$ \\
\hline \multicolumn{2}{|c|}{ Біохімічна відповідь } \\
\hline Після 12 тижнів ПВТ & $35 / 36(97,1 \%)$ & $20 / 25(80 \%)$ \\
\hline До кінця лікування & $35 / 36(97,1 \%)$ & $20 / 25(80 \%)$ \\
\hline До кінця наступного спостереження & $34 / 36(94,3 \%)$ & \\
\hline
\end{tabular}

Біохімічну відповідь після 12 тижнів терапії відзначали у 97,1 і 84,0 \% пацієнтів ХГС, до закінчення лікування - у 97,1 і 80,0 \%, до закінчення періоду спостереження - у 94,3 і 80,0 \% у групах А і Б відповідно.

Відсутність відповіді на терапію в обох групах було представлено всіма відомими варіантами - рецидивом і первинною відсутністю відповіді.

Аналіз безпеки аналізованих схем терапії ХГС

Переносимість терапії в обох групах була задовільною. Побічні ефректи були представлені переважно грипоподібним синдромом, анемією, нейтропенією, тромбоцитопенією. Частота нейтропенії і депресії в групі ПегІФН- $\alpha 2$ достовірно перевищувала таку в групі ІФН- $\alpha 2 b(p<0,05)$. Зниження концентрації гемоглобіну, пов'язане, в першу чергу, з прийомом рибавірину, спостерігалось майже у половини хворих обох груп. Кількість лейкоцитів так само знижувалася в двох групах пацієнтів, однак не вимагала корекції дози ІФН (ПЕГ ІФН) або відміни лікування. У всіх хворих рівень тромбоцитів під час лікування перевищував 100 Г/л. В жодному випадку ми не спостерігали серйозних побічних ефектів, які могли б бути причиною припинення терапії або представляли б загрозу здоров'ю пацієнта. Таким чином, побічні реакції, які виникали на ПВТ, не вимагали додаткових витрат на їх корекцію, тому в фрармакоекономічного аналізу ми їх не враховували.

Результати розрахунку вартості курсу лікування ХГС за двома аналізованими схемами представлені в таблиці 3. Більш витратною схемою лікування є терапія 3 використанням ПЕГ-ІФН+Рибавірин (Пегасис, Roche (Швейцарія) + Копегус, Roche (Швейцарія) 3 вартістю курсу лікування \$ 8354,7, менш витратною $€$ терапії 3 використанням ІФН+Рибавірин (Роферон-A, Roche (Швейцарія) + Копегус, Roche (Швейцарія) - \$ 4561,1.

Оцінка ефрективності витрат аналізованих схем лікування ХГС

Показник ефрективності витрат (CER) показує вартість одиниці ефективності при використанні відповідної медичної технології. Результати розрахунку вартості одиниці ефективності аналізованих схем лікування ХГС представлені в таблиці 4. Аналіз отриманих результатів свідчить, що більша ефективність витрат (менша вартість одиниці ефективності - \$6334,8 на одного хворого із СВВ) характерна для схеми лікування ХГС комбінова- 
ною терапією з використанням ІФН+Рибавірин. Менша ефрективність витрат була при застосуванні комбінованої терапії, що включає ПЕГ-ІФН+Рибавірин (вартість одиниці ефективності склала \$ 9114,1 на одного хворого із (BВ), тобто ефективність витрат була меншою в порівнянні $з$ комбінованою терапією ІФН+Рибавірин. Проте комбінація пегільованого інтерферону з рибавірином має значні переваги в показнику ефективності та $€$ привабливою для споживачів з наявними фрінансовими можливостями. При цьому вартість одного додаткового хворого із СВВ при застосуванні цієї схеми замість першої (оптимальною з точки зору вартості одиниці ефрективності) зажадає додаткових витрат у розмірі \$18968,0.

Таблиця 3

Аналіз витрат на досліджувані схеми лікування ХВГС

\begin{tabular}{|c|c|c|c|c|c|c|c|c|}
\hline $\begin{array}{c}\text { Групи } \\
\text { хворих }\end{array}$ & $\begin{array}{c}\text { Кількість } \\
\text { хворих }\end{array}$ & Препарати & $\begin{array}{c}\text { Торгова } \\
\text { назва }\end{array}$ & Форма випуску & $\begin{array}{l}\text { Ціна } \\
\text { за уп. } \\
\text { \$ }\end{array}$ & $\begin{array}{c}\text { схема } \\
\text { призначення }\end{array}$ & $\begin{array}{c}\text { Період } \\
\text { прийому } \\
\text { препаратів, } \\
\text { тижні }\end{array}$ & $\begin{array}{c}\text { Вартість курсу } \\
\text { лікування } \\
\text { одного } \\
\text { хворого,\$ }\end{array}$ \\
\hline \multirow[t]{2}{*}{ A } & \multirow[t]{2}{*}{25} & \multirow[t]{2}{*}{$\begin{array}{l}\text { ІФН + } \\
\text { рибавірин }\end{array}$} & $\begin{array}{l}\text { PОФЕРОН-А, } \\
\text { Roche } \\
\text { (Швейцарія), }\end{array}$ & $\begin{array}{l}\text { p-н д / ін. } 3000000 \\
\text { МО шприц-тюбик } \\
0,5 \text { мл, № } 1\end{array}$ & 25,3 & $\begin{array}{c}3 \text { млн. МO } \\
3 \text { р.в } \\
\text { тиждень }\end{array}$ & \multirow{2}{*}{24} & \multirow[t]{2}{*}{$\begin{array}{l}1832,1 \\
2728,7 \\
\sum 4561,1\end{array}$} \\
\hline & & & $\begin{array}{l}\text { КОПЕГУС, } \\
\text { Roche } \\
\text { (Швейцарія), }\end{array}$ & $\begin{array}{l}\text { табл. п / плівчастою } \\
\text { оболонкою } 200 \text { мг, } \\
\text { №168 }\end{array}$ & 272,9 & $\begin{array}{c}1000-1200 \text { мг } \\
2 \text { р. на добу }\end{array}$ & & \\
\hline \multirow[t]{2}{*}{ Б } & \multirow[t]{2}{*}{36} & \multirow[t]{2}{*}{$\begin{array}{l}\text { ПЕГ-ІФН + } \\
\text { рибавірин }\end{array}$} & $\begin{array}{l}\text { ПЕГАСИС, } \\
\text { Roche } \\
\text { (Швейцарія) }\end{array}$ & $\begin{array}{l}\text { p-н д / ін. } 180 \text { мкг } \\
\text { шприц-тюбик 0,5 мл, } \\
\text { № } 1\end{array}$ & 302,5 & $\begin{array}{c}180 \text { мкг } \\
\text { в тиждень п/ } \\
\text { шк }\end{array}$ & \multirow{2}{*}{24} & \multirow[t]{2}{*}{$\begin{array}{l}7263,2 \\
1091,4 \\
\sum 8354,7\end{array}$} \\
\hline & & & $\begin{array}{l}\text { КОПЕГУС, } \\
\text { Rосhе } \\
\text { (Швейцарія) }\end{array}$ & $\begin{array}{l}\text { табл. п / плівчастою } \\
\text { оболонкою } 200 \text { мг, } \\
\text { № } 168\end{array}$ & 272,9 & $\begin{array}{c}800 \text { мг щодня } \\
\text { всередину }\end{array}$ & & \\
\hline
\end{tabular}

Таблиця 4

Ефективність витрат на досліджувані схеми лікування ХВГС

\begin{tabular}{|c|c|c|c|c|c|c|}
\hline $\begin{array}{c}\text { Група } \\
\text { хворих }\end{array}$ & $\begin{array}{c}\text { Кількість } \\
\text { хворих }\end{array}$ & Вид терапії & $\begin{array}{c}\text { Кількість хворих } \\
\text { з СВВ через } \\
24 \text { тижні після } \\
\text { лікування, (\%) }\end{array}$ & $\begin{array}{c}\text { Вартість курсу } \\
\text { лікування } \\
\text { одного } \\
\text { хворого, \$ }\end{array}$ & $\begin{array}{c}\text { Вартість одиниці } \\
\text { ефективності, } \\
\text { \$ / одного хворого } \\
\text { із СВВ }\end{array}$ & $\begin{array}{c}\text { Вартість } \\
\text { додаткової одиниці } \\
\text { ефрективності, \$ / } \\
\text { одного додаткового } \\
\text { хворого із СВВ }\end{array}$ \\
\hline A & 25 & $\begin{array}{c}\text { ІФН + } \\
\text { рибавірин }\end{array}$ & $18(72,0)$ & 4561,1 & 6334,8 & - \\
\hline 5 & 36 & $\begin{array}{l}\text { ПЕГ-ІФН + } \\
\text { рибавірин }\end{array}$ & $33(91,6)$ & 8354,7 & 9114,1 & 18968,0 \\
\hline
\end{tabular}

\section{Висновки}

Порівняльний фрармакоекономічний аналіз двох схем противірусної терапії ХГС, генотип 2/3, продемонстрував, що більша ефрективність витрат характерна для терапії ІФН + рибавірин. Незважаючи на дещо меншу клінічну есрективність (на 20 \%), співвідношення вартості лікування в перерахунку на одного хворого виявилося кращим. Ця схема терапії має економічну перевагу, якщо лікування хворих фрінансується за рахунок національних програм і ставиться завдання вилікувати не конкретного хворого, а якомога більшу кількість пацієнтів. Однак така схема лікування ХГС має меншу клінічну ефективність, тому для пацієнта більш привабливою залишається терапія ПЕГ-ІФН + рибавірин, яка забезпечує більшу частоту СВВ та менший за величиною показник ефективності витрат.

\section{Література}

1. Хасин А. Результаты клинических исследований, проведенных в ведущих медицинских центрах Германии / А. Хасин // Современный взгляд на проблему лечения гепатита С в Европе. - Москва, 2005. - С. 1-4.

2. The contribution of hepatitis B virus and hepatitis $C$ virus infections to cirrhosis and primary liver cancer worldwide / J. Perz, G. Armstrong, L. Farrington et al. // J. Hepatol. - 2006. - Vol. 45. P. 529-538.

3. Ивашкин В.Т. Диагностика, лечение и ведение пациентов с гепатитом C (По материалам практических рекомендаций Американского общества по изучению заболеваний печени (AASLD) 


\section{ОРИГІНАЛЬНІ ДОСЛІДЖЕННЯ}

/ В.Т. Ивашкин // Клиническая микробиология и антимикробная химиотерапия. - 2006. - Т. 8, № 2. - С. 102-129.

4. Современное состояние и проблемы эпидемиологии гепатита С в Украине / А.Л. Гураль, В.Ф. Мариевский, Т.А. Сергеева и др. // Мир вирусных гепатитов. - 2009. - № 2. - С. 27.

5. Гураль А.Л. Современное состояние проблемы парентеральных вирусных гепатитов в Украине / А.Л. Гураль, Ж.Б. Клименко // Здоров'я України. - 2011. - № 1(19). - С. 40-41.

6. Гепатит С в Україні: невизнана епідемія. Правовий, медичний та соціальний аналіз: // http // hepatit.org.ua/wp-content/ uploads/2010/02/HCV-UA-report-2009.pdf.

7. Peginterferon-alpha2a and ribavirin combination therapy in chronic hepatitis $\mathrm{C}$ : a randomized study of treatment duration and ribavirin dose / S.J. Hadziyannis, H.Jr. Sette, T.R. Morgan et al. // Ann. Intern. Med. - 2004. - Vol. 140. - P. 346-355.

8. International, multicenter, randomized, controlled study comparing dynamically individualized versus standard treatment in patients with chronic hepatitis C / S. Zeuzem, J.M. Pawlotsky, E. Lukasiewicz et al. // Hepatology. - 2005. - Vol. 43. - P. 250-257.

9. Randomized, double-blind, placebo-controlled study of peginterferon alfa-2a (40KD) plus ribavirin with or without amantadine in treatment-naive patients with chronic hepatitis $C$ genotype 1 infection / P. Ferenci, E. Formann, H. Laferl et al. // Hepatology. - 2006. - Vol. 44. - P. 275-282.

10. Peginterferon-alpha-2a (40KD) and ribavirin for 16 or 24 weeks in patients with genotype 2 or 3 chronic hepatitis C / M. Wagner, M. Huber, T. Berg et al. // Gastroenterology. - 2005. - Vol. 129. - P. 522-527.

11. Peginterferon alfa-2a and ribavirin for 16 or 24 weeks in HCV genotype I or 3 / M.L. Shiffman, F. Suter, B.R. Bacon et al. // N. Engl. J. Med. - 2007. - Vol. 357. - P. 124-130.

12. Peginterferon alfa-2b plus ribavirin for treatment of chronic hepatitis $\mathrm{C}$ in previously untreated patients infected with HCV genotypes 2 or 3 / S. Zeuzem, R. Hultcrantz, M. Bourliere et al. // Hepatology. - 2004. - Vol. 40. - P. 993-999.

13. Peginterferon alfa-2b and ribavirin for 12 vs. 24 weeks in $\mathrm{HCV}$ genotype 2 or 3 / A. Mangia, R. Santoro, N. Minerva et al. // N. Engl. J. Med. - 2005. - Vol. 352. - P. 2609-2617.

14. Weight-based ribavirin dosing (WBD) increases sustained viral response (SVR) in patients with chronic hepatitis $\mathrm{C}(\mathrm{CHC})$ : final results of the WIN-R study, a US community based trial / I.M. Jacobson, R.S. Brown, B. Freilich et al. // Hepatology. - 2005. - Vol. 42, Suppl. 1. - P. 749A.

15. Hepatitis $C$ viral dynamics in vivo and the antiviral efficacy of interferon-alpha therapy / A.U. Neumann, N.P. Lam, H. Dahari et al. // Science. - 1998. - Vol. 282. - P. 103-107.

16. Cost-effectiveness of ribavirin plus interferon alpha-2b for either interferon relapsers or non-responders in chronic hepatitis $\mathrm{C}: \mathrm{a}$
Japanese trial / H. Ishida, Y. Inoue, J.B. Wong et al. // Hepatol. Res. - 2004. - Vol. 28. - P. 125-136.

17. Вирусные гепатиты / Ю.В. Лобзин, К.В. Жданов, В.М. Волжанин, Д.А. Гусев. - СПб: ИКФ «Фолиант», 2006. - 192 с.

18. Прикладная фрармакоэкономика: Учебное пособие / Под ред. В.И. Петрова. - М.: ГЭОТАР-Медиа, 2005. - 336 с.

19. Фармакоэкономика: Учеб. пособие для студентов вузов / Л.В. Яковлева, Н.В. Бездетко, О.А. Герасимова и др.; под ред. Л.В. Яковлевой. - Харьков: Изд-во НФаУ: Золотые страницы, 2007. - 176 c

\section{ANTIVIRAL THERAPY OF $2 / 3$ GENOTYPES OF HEPATITIS C VIRUS: CLINICAL AND COST ANALYSIS OF ITS EFFECTIVENESS}

\author{
V.T. Kiriyenko, I.A. Zaitsev, V.V. Potiy
}

SUMMARY. In the article evaluated the comparative clinical and cost effectiveness of two schemes of antiviral therapy for chronic hepatitis $C$, genotype 2/3 $\mathrm{HCV}$. Group A patients $(n=25)$ received a combination of interferon-a and ribavirin, Group $B$ patients $(n=36)$ pegylated interferon-a with ribavirin. The frequency of obtaining early virological response and response by the therapy of termination of the course $-80 \%$ and $94.3 \%$, SVR - $72 \%$ and $91.7 \%$ in group $A$ and $B$, respectively ( $p>0,05$ for all values). Comparative pharmacoeconomic analysis of two schemes of antiviral therapy of HCV genotype 2/3, showed that higher cost efficiency is typical for the combination therapy of IFN-a + ribavirin. This scheme therapy has a significant economic advantage if treatment is funded by national programs and seeks not cure a particular patient, and the largest possible number of patients. However, this regimen such a regimen of $\mathrm{CHC}$ has less clinical efficacy, therefore for the patient is more attractive therapy of PEG-IFN-a plus ribavirin, which provides greater SVR and lower indicator of cost effectiveness.

Key words: chronic hepatitis C, pegylated interferon-a, interferon-a, ribavirin, pharmacoeconomic analysis.

Отримано 30.02.2015 р. 